\title{
Correlation of Serum Estradiol and Progesterone Levels with Endometrial Expression of Estrogen Receptor $\alpha$ in Abnormal Uterine Bleeding Endometrium Cases in Reproductive Age Group
}

\author{
${ }^{1}$ Priya Singh, ${ }^{2}$ Vishal Dhingra, ${ }^{3}$ Amrita Chaurasia, ${ }^{4}$ Pallavi Singh, ${ }^{5}$ Vatsala Misra, ${ }^{6}$ Beenu Doctor
}

\begin{abstract}
Aim: Abnormal uterine bleeding (AUB) is a common cause for gynecological referrals. Serum correlation of hormone levels along with study of expression of estrogen receptor (ER) and progesterone receptor (PR) in the endometrium of patients with AUB may be helpful in deciding treatment.
\end{abstract}

Materials and methods: Forty AUB-endometrium (AUB-E) cases classified as per PALM-COEIN (polyp, adenomyosis, leiomyoma, malignancy and hyperplasia, coagulopathy, ovulatory disorders, endometrium, iatrogenic, and not classified) classification were assessed. Endometrial biopsies were stained with hematoxylin and eosin (H\&E) for histomorphological details and immunohistochemistry (IHC) for quantification of ER $\alpha$ and PR expression in AUB-E cases. Serum samples were obtained on the day of biopsy and examined for serum estrogen and serum progesterone levels. Unpaired Student's t-test was used for statistical calculation and $p=0.05$ value was taken as critical level of significance.

Results: Serum estradiol was decreased in 10\%, normal in $65 \%$, and increased in $25 \%$ cases. Serum progesterone levels were decreased in $52.5 \%$, normal in $30 \%$, and increased in $17.5 \%$. Correlation of ER $\alpha$ with serum estradiol levels showed an inverse relationship. The difference was statistically significant $(p=0.04)$.

Conclusion: In AUB-E cases, a hyperestrogenic state may be due to true/relative increase in serum estradiol levels. Decreased serum estradiol levels present with changes of hyperestrogenism may be due to overexpression of ER $\alpha$ receptors. Both expressions of receptors in endometrium and serum hormone levels play a role in the final outcome of hyperestrogenic state. Therefore, patients with normal or decreased serum estradiol levels may be investigated for expression of ER $\alpha$ in endometrium for deciding the final treatment.

\footnotetext{
${ }^{1}$ Pathologist, ${ }^{2,4}$ Assistant Professor, ${ }^{3,6}$ Associate Professor ${ }^{5}$ Professor and Head

1,2,4,5Department of Pathology, Moti Lal Nehru Medical College Allahabad, Uttar Pradesh, India

${ }^{3}$ Department of Obstetrics and Gynecology, Moti Lal Nehru Medical College, Allahabad, Uttar Pradesh, India

${ }^{6}$ Department of Biochemistry, Moti Lal Nehru Medical College Allahabad, Uttar Pradesh, India

Corresponding Author: Priya Singh, Pathologist, Department of Pathology, Moti Lal Nehru Medical College, Allahabad, Uttar Pradesh, India, Phone: +919451844401, e-mail: drpriyasingh $121 @ g m a i l . c o m$
}

Clinical significance: Patients with AUB-E with normal or decreased hormonal levels should be investigated for ER $\alpha$ in endometrial biopsy to decide optimal hormonal therapy.

Keywords: Abnormal uterine bleeding, Abnormal uterine bleeding-endometrium, Estrogen receptor $\alpha$, PALM-COEIN.

How to cite this article: Singh $P$, Dhingra V, Chaurasia A, Singh P, Misra V, Doctor B. Correlation of Serum Estradiol and Progesterone Levels with Endometrial Expression of Estrogen Receptor a in Abnormal Uterine Bleeding Endometrium Cases in Reproductive Age Group. J South Asian Feder Obst Gynae 2018;10(1):5-9.

\section{Source of support: Nil}

Conflict of interest: None

Date of received: 15 January 2018

Date of acceptance: 25 February 2018

Date of publication: May 2018

\section{INTRODUCTION}

Abnormal uterine bleeding is defined as an alteration in the volume, pattern, and / or duration of menstrual blood flow and remains the most common reason for gynecologic referrals. ${ }^{1,2}$ International Federation of Gynecology and Obstetrics (FIGO) came up with PALM-COEIN classification for AUB in nongravid women in reproductive age groups. The system is categorized into nine major categories known as PALM-COEIN. ${ }^{3}$ The causes of PALM group are structural and measurable visually, by using imaging techniques and/or by use of histopathology, while the COEIN group is related to entities that cannot be determined by imaging or histopathology alone. ${ }^{4}$ The AUB-endometrium may arise either due to hormonal imbalance or due to inadequate prostaglandins. ${ }^{5,6}$ Estrogen and progesterone exert their effect by acting on specific nuclear receptor proteins, ER and PR. These receptors are present in endometrial stromal and glandular cells. ${ }^{7}$ The ERs and PRs are placed in nuclear steroid receptor superfamily. ${ }^{8}$ Estrogen and progesterone mediate their effect through intra- and extranuclear receptors. The ER exists in two forms: ER $\alpha$ and ER $\beta .^{9}$ The PR receptor occurs in PR-A and PR-B. ${ }^{7}$ The IHC is helpful because of tissue localization and aids in assessing tissue 


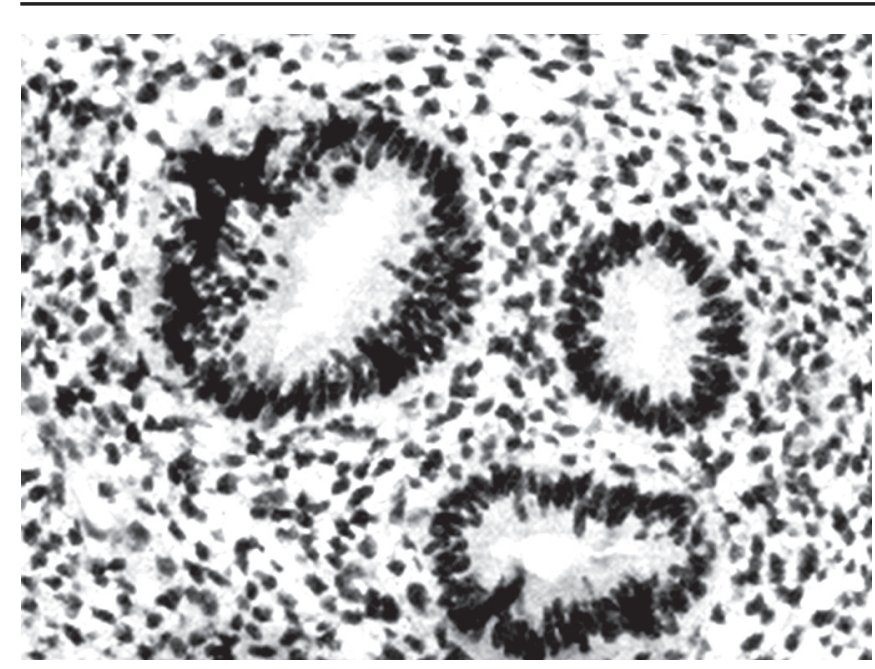

Fig. 1: ERa expression in glands $3 \times 4$ and stroma $3 \times 4(400 \times)$

distribution and intensity in glandular and stromal cells. ${ }^{10}$ Treatment of AUB includes both medical therapies and surgical procedures. ${ }^{11}$ Surgical treatment should be used for patients who are clinically unstable, not suitable for medical management, or have inappropriate response to medical therapy. ${ }^{12}$ Since hormonal treatment forms the first-line treatment, ${ }^{13,14}$ study of hormonal levels along with receptor expression may prove to be beneficial in deciding the treatment plans of this group. Till date no well-documented study is available in literature, which correlated serum hormone levels with ER $\alpha$ expression.

\section{MATERIALS AND METHODS}

A cross-sectional study for the period from July 2014 to August 2015 was performed in patients presenting with AUB in reproductive age group in nongravid women. All endometrial specimens from patients of age group 15 to 45 years presenting with complaints of AUB were classified as per PALM-COEIN classification in nongravid women in reproductive age group. Females of age group 15 to 45 presenting with AUB were included. Any female presenting with systemic diseases like diabetes mellitus, hypertension, chronic liver and kidney disease, and organic genital tract lesion were excluded from the present study. Patients presenting with mental illness were also excluded. Endometrial biopsy was stained with H\&E and examined thoroughly to note the histopathological details and classified as per FIGO (PALM-COEIN) and World Health Organization classification. In 40 AUB-E cases, serum estradiol and progesterone levels were estimated by chemiluminescence method (Immulite 1000). Midluteal phase levels were taken as normal reference range as all biopsies were obtained in premenstrual phase (normal estradiol levels $=27-246 \mathrm{pg} / \mathrm{mL}$; normal progesterone levels $=2.83-26.1 \mathrm{ng} / \mathrm{mL}$ ). The IHC for quantification of ER $\alpha$ and PR expression was carried out in AUB-E cases. For IHC 20 control samples were taken from hysterectomy

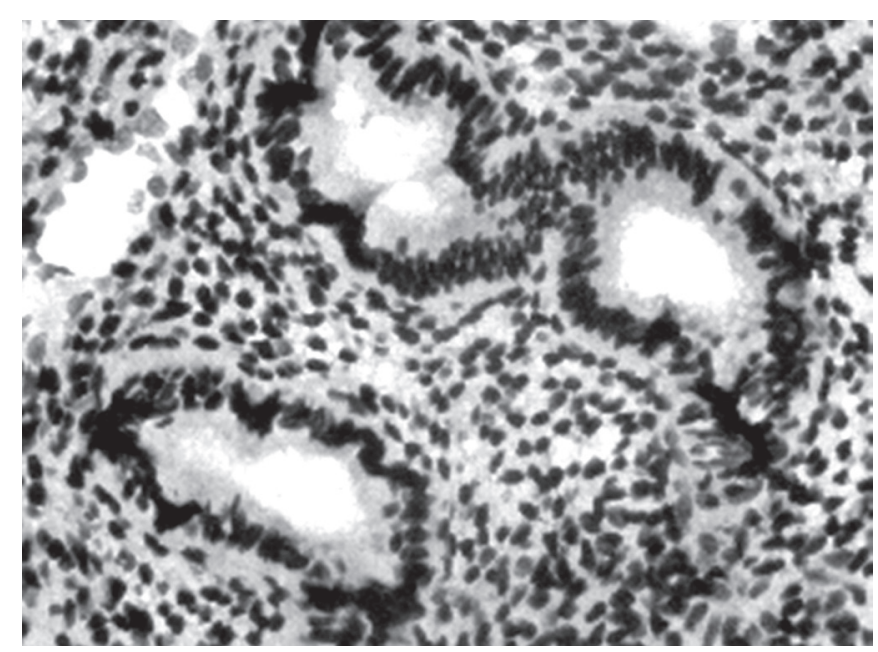

Fig. 2: $P R$ expression in glands $3 \times 4$ and stroma $3 \times 4(400 \times)$

specimen of similar age group presenting with vaginal prolapse. Primary antibody used for ER $\alpha$ was monoclonal mouse anti-ER clone ID5 (BioGenex, Fremont, CA) and for PR was monoclonal mouse anti-PR clone PR88 (BioGenex, Fremont, CA). A case was considered positive when brown coloration of the nucleus was observed. Expression of ER $\alpha$ and PR receptors was positive in endometrial lining cells as well as in stroma. Intensity and distribution of ER $\alpha$ and PR were evaluated using a semi-quantitative method Immunoreactive score (IRS score) ${ }^{15}$ (Figs 1 and 2). The IRS score was calculated as follows: IRS $=\mathrm{SI} \times \mathrm{PP}$, where $\mathrm{SI}$ is the optical staining intensity (graded as $0=$ no, 1 = weak, 2 = moderate, and $3=$ strong staining) and PP the percentage of positive-stained cells. The PP was estimated by counting approximately 200 cells and it was defined as $0=$ no staining, $1=<10 \%, 2=11$ to $50 \%$, $3=51$ to $80 \%$ and $4=>81$. Unpaired Student's t-test was performed to compare the results in various groups. A $\mathrm{p}$-value $\leq 0.05$ was taken as critical level of significance.

\section{RESULTS}

In AUB-E cases, serum estradiol and progesterone were compared with normal reference range of our laboratory and they were classified as having decreased, normal, or increased levels Out of 40 cases studied $4 / 40(10 \%)$ had decreased serum estradiol levels, 26/40 (65\%) cases had normal serum estradiol levels, $10 / 40$ (25\%) cases had increased serum estradiol levels. Serum progesterone was decreased in $21 / 40(52.5 \%)$, normal in $12 / 40(30 \%)$, and increased in $7 / 40$ (17.5\%) (Table 1). When serum

Table 1: Number of AUB-E patients showing decreased, normal, or increased serum estradiol and progesterone

\begin{tabular}{llll}
\hline Serum levels & $\begin{array}{l}\text { Decreased } \\
\text { levels }\end{array}$ & $\begin{array}{l}\text { Normal } \\
\text { levels }\end{array}$ & $\begin{array}{l}\text { Increased } \\
\text { levels }\end{array}$ \\
\hline Serum estradiol & $4(10 \%)$ & $26(65 \%)$ & $10(25 \%)$ \\
Serum progesterone & $21(52.5 \%)$ & $12(30 \%)$ & $7(17.5 \%)$ \\
\hline
\end{tabular}


Table 2: ER $\alpha$ expression scores in patients with normal estradiol but variable progesterone

\begin{tabular}{llll}
\hline Normal estradiol levels; progesterone levels & ER $\alpha$ gland mean (SD) & ER $\alpha$ stroma mean (SD) & ER total score mean (SD) \\
\hline Decreased progesterone & $8.12(4.37)$ & $7.75(3.79)$ & $15.85(6.08)$ \\
Normal progesterone & $8.2(3.42)$ & $6.5(3.91)$ & $14.7(6.21)$ \\
Increased progesterone & $8(0)$ & $12(0)$ & $20(0)$ \\
\hline
\end{tabular}

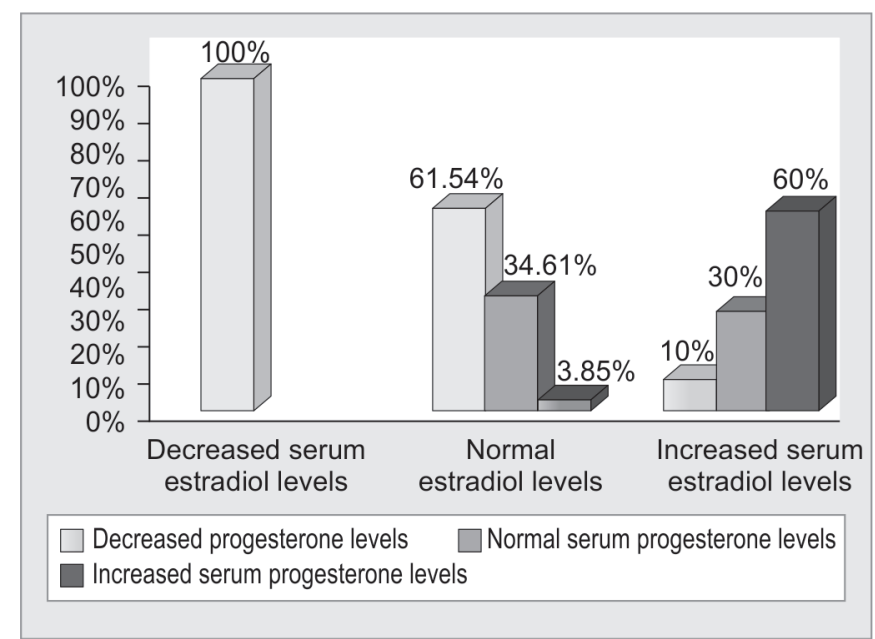

Graph 1: Serum progesterone levels in relation to serum estradiol levels

progesterone levels were evaluated in relation to serum estradiol levels, in four cases with decreased serum estradiol levels progesterone levels were also decreased. Out of 26 cases with normal serum estradiol levels, 9/26 (34.61\%) cases had normal serum progesterone levels, $16 / 26(61.54 \%)$ cases had decreased serum progesterone levels, and 1/26 (3.85\%) case had increased serum progesterone levels. Out of 10 cases of increased serum estradiol levels, $3 / 10(30 \%)$ cases had normal, 1/10 (10\%) had decreased, and 6/10 (60\%) cases had increased serum progesterone levels (Graph 1).

When status of ER $\alpha$ expression in patients with normal estradiol levels but variable progesterone was evaluated in cases with decreased or normal serum progesterone, expression of ER $\alpha$ in glands was more as compared with stroma. One case with increased serum level had increased ER $\alpha$ expression in stroma as compared with glands (Table 2), thus highlighting the role of serum progesterone in stromal expression of ER $\alpha$.

The ER $\alpha$ expression when correlated with serum estradiol in four cases with decreased serum estradiol levels (17.6 pg/mL) had maximum scores (20.5). Twentysix cases with normal serum estradiol levels (101.146 pg/ $\mathrm{mL}$ ) had total score (16.96) more than increased group (13.5). Ten cases with increased serum estradiol levels had lowest $E R \alpha$ (13.5) and mean serum values were maximum $(1,389.3)$. When mean [standard deviation (SD)] ER $\alpha$ expression of patients with increased serum estradiol of the lowest (13.5) was compared with those of decreased serum estradiol levels (20.5), the difference was found

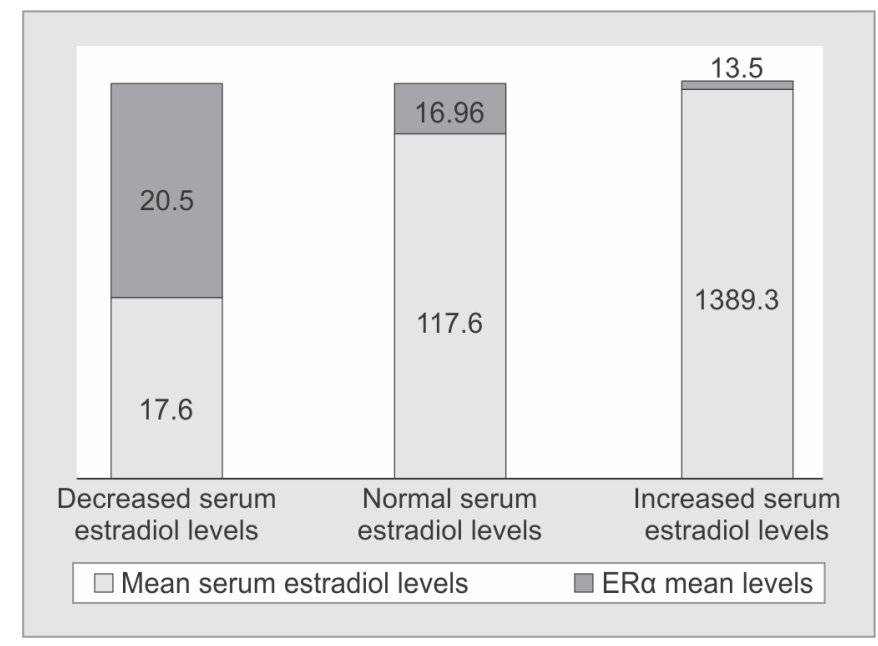

Graph 2: Expression of ER $\alpha$ score in relation to serum estradiol levels

to be statistically significant $(\mathrm{p}<0.0432)$ (Graph 2$)$, thus establishing an inverse relation between serum estradiol levels and ER $\alpha$ expression. When levels of serum estradiol were compared with ER expression a clear inverse relation was observed. Patients with increases in serum estradiol (mean SD 1389.3) had ER score (13.5) in contrast to decreased serum estradiol levels $(17.6 \mathrm{pg} / \mathrm{mL})$ where ER score was 20.5.

PR receptor expression was not considered very significant because it did not show any significant variation to hyperestrogenic state.

\section{DISCUSSION}

Of 40 patients in whom serum estradiol levels were measured, $10 \%$ had decreased, $65 \%$ had normal, and $25 \%$ showed increased levels. Serum progesterone levels were decreased in 52.5\%, normal in 30\%, and increased in $17.5 \%$, thereby highlighting hormonal discrepancy in cases of AUB. When serum progesterone was evaluated in relation to serum estradiol levels, $10 \%$ cases with decreased serum estradiol had decreased progesterone levels, also highlighting the hormonal insufficiency. Out of $65 \%$ cases where serum levels of estradiol were normal, serum progesterone levels of $34.61 \%$ were also normal, implying local factors like endothelins or prostaglandins as the cause of AUB; $61.53 \%$ had decreased serum levels of progesterone, thereby creating a relative hyperestrogenic state. It is known that unopposed estrogen leads to excessive endometrial proliferation and hyperplasia with raised and dilated draining veins and suppression 
of spiral arterioles. ${ }^{16}$ Unopposed estrogen leads to direct effect on uterine blood supply by causing decreased vascular tone ${ }^{17}$ which may be an indirect effect through inhibiting vasopressin release ${ }^{18}$ causing vasodilation and increased blood flow. Unopposed estrogen also increases stromal vascular endothelial growth factor expression that may lead to disrupted angiogenesis. ${ }^{19}$ Additionally, endometrium exposed to prolonged estrogen produces less prostaglandin and more of prostaglandin $\mathrm{E}$ than prostaglandin $\mathrm{F}^{20}$ In $3.84 \%$ where progesterone was increased probably stromal or vascular factors may be responsible for AUB. ${ }^{5,6}$

In cases with increased serum estradiol levels, progesterone levels were normal in $30 \%$ and low in $10 \%$ but none had higher levels, thus creating a hyperestrogenic state causing AUB; $60 \%$ cases who presented with high progesterone levels in this group had disproportionally high $(>2,000 \mathrm{pg} / \mathrm{mL})$ serum estradiol levels, thus again creating a relatively hyperestrogenic state causing AUB. ${ }^{16-20}$

When ER $\alpha$ receptor expression was assessed in relation to serum estradiol levels, a decreasing trend in expression of ER $\alpha$ receptor was found with increased levels of mean estradiol levels. Patients with decreased serum estradiol $(17.6 \mathrm{pg} / \mathrm{mL})$ had mean receptor expression score of 20.5, whereas patients with markedly increased serum estradiol levels $(1,389.3 \mathrm{pg} / \mathrm{mL})$ had mean ER $\alpha$ expression of 13.5 only. Difference between two groups was statistically significant $(\mathrm{p}<0.04)$, thus highlighting that both serum estradiol levels and expression of ER have a role in the process of hyperestrogenemia and probably patients with decreased serum estradiol levels present with changes of hyperestrogenesim due to overexpression of $\mathrm{ER} \alpha$ receptors.

No well-documented study could be found in literature comparing the serum hormone levels with expression of tissue receptor except by Chakravarthy et a ${ }^{21}$ who also noted discrepancy in patients presenting with dysfunctional uterine bleeding (term discouraged by FIGO now) but details were not specified. One of the limitations of the study was the small sample size since the duration of the study was short, and a larger study is required to further validate the results. High cost of assessment of serum hormone levels and tissue ER $\alpha$ receptor may be a distracting factor but when considered in relation to suboptimal therapy/unwanted prolonged hormonal therapy it may not appear expensive.

\section{CONCLUSION}

In AUB-E cases a hyperestrogenic state may be due to true/ relative increase in serum estradiol levels. Both expression of receptors in endometrium and serum hormone levels play a role in final outcome of hyperestrogenic state.
Therefore, patients with AUB-E with normal or decreased serum estradiol may be investigated for expression of ER $\alpha$ in endometrium for deciding the final line of treatment.

\section{CLINICAL SIGNIFICANCE}

As hormonal imbalance is a key mechanism for AUB, patients presenting with AUB-E with normal or decreased hormonal levels should be investigated for ER $\alpha$ in endometrial biopsy to decide optimal hormonal therapy as expression of receptors in endometrium and serum hormone levels play a role in final outcome of hyperestrogenic state.

\section{ACKNOWLEDGMENT}

The authors would like to thank their technical staff for their help.

\section{REFERENCES}

1. Rahn DD, Abed H, Sung VW, Matteson KA, Rogers RG, Morrill MY, Barber MD, Schaffer JI, Wheeler TL, Balk EM, et al. Systematic review highlights difficulty interpreting diverse clinical outcomes in abnormal uterine bleeding trials. J Clin Epidemiol 2011 Mar;64(3):293-300.

2. Matteson KA, Boardman LA, Munro MG, Clark MA. Abnormal uterine bleeding: a review of patient-based outcome measures. Fertil Steril 2009 Jul;92(1):205-216.

3. Munro MG, Critchley HO, Broder MS, Fraser IS; FIGO Working Group on Menstrual Disorders. FIGO classification system (PALM-COEIN) for causes of abnormal uterine bleeding in nongravid women of reproductive age. Int J Gynaecol Obstet 2011 Apr;113(1):3-13.

4. Munro MG, Critchley HO, Fraser IS; FIGO Menstrual Disorders Working Group. The FIGO classification of causes of abnormal uterinebleeding in the reproductive years. Fertil Steril 2011 Jun;95(7):2204-2207.

5. Dodds, N.; Sinert, RH. Dysfunctional uterine bleeding. In: Conrad SA, editor. Emedicine. 2007. [cited 2008 Apr 24]. Available from: http://emedicine.medscape.com/article/ 795587-overview.

6. Nelson, AL. Menstrual problems and common gynecologic concerns. In: Hatcher RA, Trussell J, Stewart F, Nelson AL, Cates W Jr, Guest F, Kowal D, editors. Contraceptive technology. 18th ed. New York: Ardent Media; 2004. pp. 121-126.

7. Clark JH, Peck EJ Jr. Female sex steroid receptors and function. Monogr Endocrinol 1979;14:1-12, 1-245.

8. Mylonas I, Jeschke U, Shabani N, Kuhn C, Kriegel S, Kupka MS, Friese K. Normal and malignant human endometrium express immunohistochemically estrogen receptor alpha $(E R \alpha)$, estrogen receptor beta $(E R \beta)$ and progesterone receptor (PR). Anticancer Res 2005 May-Jun;25(3A):1679-1686.

9. Klinge CM. Estrogen receptor interaction with estrogen response elements. Nucleic Acids Res 2001 Jul;29(14): 2905-2919.

10. Press MF, Udove JA, Greene GI. Progesterone receptors distribution in the human endometrium. Am J Pathol 1988 Apr;131(1):112-124.

11. Liu Z, Doan QV, Blumenthal P, Dubois RW. A systematic review evaluating health-related quality of life, work impairment, and 
health-care costs and utilization in abnormal uterine bleeding. Value Health 2007 May-Jun;10(3):183-194.

12. American College of Obstetricians and Gynecologists. Management of acute abnormal uterine bleeding in nonpregnant reproductive-aged women. Committee Opinion No. 557. Obstet Gynecol 2013 Apr;121:891-896.

13. Samuel NC, Clark TJ. Future research into abnormal uterine bleeding. Best Pract Res Clin Obstet Gynaecol 2007 Dec;21(6): 1023-1040.

14. Telner DE, Jakubovicz D. Approach to diagnosis and management of abnormal uterine bleeding. Can Fam Physician 2007 Jan;53(1):58-64.

15. Remmele W, Stegner HE. Vorschlag zur einheitlichen Definierung eines immunreaktiven Score (IRS) für den immunhistochemischen Östrogenrezeptornachweis (ERs-ICA) im Mammakarzinomgewebe. Pathologe 1987 May;8(3):138-140.

16. Beilby JO, Farrer-Brown G, Tarbit MH. The microvasculature of common uterine abnormalities, other than fibroids. J Obstet Gynaecol Br Commonw 1971 Apr;78(4):361-368.
17. Fraser IS, McCarron G, Hutton B, Macey D. Endometrial blood flow measured by xenon 133 clearance in women with normal menstrual cycle and dysfunctional uterine bleeding. Am J Obstet Gynaecol 1987 Jan;156(1):158-166.

18. Akerlund M, Bengsston LP, Carter AM. A technique for monitoring endometrial or decidual blood flow with an intrauterine thermistor probe. Acta Obstet Gynaecol Scand 1975 Jan;54(5):469-477.

19. Zhang L, Rees MC, Bicknell R. The isolation and long term culture of normal human endometrial epithelium and stroma. Expression of mRNAs for angiogenic polypeptide basally and on oestrogen and progesterone challenges. J Cell Sci 1995 Jan;108(Pt 1):323-331.

20. Smith SK, Abel MH, Kelly RW, Baird DT. The synthesis of prostaglandins from persistent proliferative endometrium. J Clin Endocrinol Metab 1982 Aug;55(2):284-289.

21. Chakravarthy VK, Nag U, Rao DR, Anusha AM. estrogen and progesterone receptors in dysfunctional uterine bleeding. J Dent Med Sci IOSR-JDMS 2013 Jan-Feb;4(3):73-76. 